УДК 811.111(07)

\title{
НАСТАВНИЦТВО В ГАЛУЗІ НАВЧАННЯ ІНОЗЕМНИХ МОВ: АНОТОВАНА БІБЛІОГРАФІЯ
}

\author{
Плотніков Є. О., Гошилик В. Б. \\ plotnikov@ndu.edu.ua; volodymyr.goshylyk@pnu.edu.ua \\ https://orcid.org/0000-0001-6010-247X; https://orcid.org/0000-0001-7645-5966 \\ Ніжинський державний університет імені Миколи Гоголя \\ Прикарпатський наиіональний університет імені Василя Стефаника \\ Дата надходження 01.11.2020. Рекомендовано до друку 02.12.2020.
}

В огляді запропоновано короткий аналіз наукових досліджень щодо наставництва в галузі навчання іноземних мов. Подано анотований огляд відповідних публікацій у провідних наукових виданнях з методики навчання іноземних мов за період з 2011 року до 2020 року.

Ключові слова: наставництво, менторинг, навчання іноземних мов, дослідження, науковий журнал.

Плотников Е. А., Гошилик В. Б.

Нежинский государственный университет имени Николая Гоголя; Прикарпатский национальный университет имени Василия Стефаника, Ивано-Франковск

Наставничество в обучении иностранным языкам: аннотированная библиография

В обзоре предложен краткий анализ научных исследований наставничества в контексте обучения иностранным языкам. Представлен аннотированный обзор соответствующих публикаций в ведущих научных изданиях по методике обучения иностранным языкам за период с 2011 года по 2020 год.

Ключевые слова: наставничество, менторинг, обучение иностранным языкам, исследования, научный журнал.

Plotnikov Y., Goshylyk V.

Nizhyn Gogol State University; Vasyl Stefanyk Precarpathian National University, Ivano-Frankivsk Mentoring in teaching foreign languages: annotated bibliography

This paper aims to investigate mentoring in foreign language teaching. The article systematically reviews the key studies conducted and published from 2011 to 2020 to reveal current trends and to show best research practices. All the analyzed publications represent the leading scientific journalsin the field of language education.

Key words: mentoring, foreign language teaching, research, scientific journal.

Зазвичай наставництво (mentoring) у різних галузях життя людини сприймається як процес, у якому більш досвідчений учитель надає психологічну та професійну підтримку менш досвідченому колезі. Під час такої діяльності очікується, що, спираючись на власні знання та досвід їх реалізації, наставник буде розвивати компетентності підлеглого шляхом спрямування й аналізу його діяльності, надання порад щодо покращення професійної практики та подолання труднощів тощо. Дослідження наставництва надають чимало підтверджень його ефективності та дозволяють скласти уявлення про шляхи та способи його реалізації.

Огляд охоплює 57 публікацій у 28-ти журналах (в середньому - 2,04 статті на журнал), що індексуються у наукометричній базі $S c o p u s$, належать до першого квартиля й були видані в період з 2011 до 2020 років. До уваги бралися видання, що належать до категорії “Мова та мовознавсто" (Language \& Linguistics) і присвячені проблемам прикладної лінгвістики та навчання іноземних мов. Статті, надруковані у 2020 році, відображено в переліку лише частково, оскільки бібліографію укладено до завершення року.

Беручи за основу об’єкт спрямування наставництва, виділимо декілька основних категорій, навколо яких зосереджено аналізовані наукові публікації, а саме наставництво студентів й учнів, наставництво вчителів-початківців, наставництво практикуючих учителів, наставництво виконавців наукових робіт, а також взаємне наставництво. На рис. 1 наведено кількісне співвідношення аналізованих публікацій згідно з цими категоріями. 


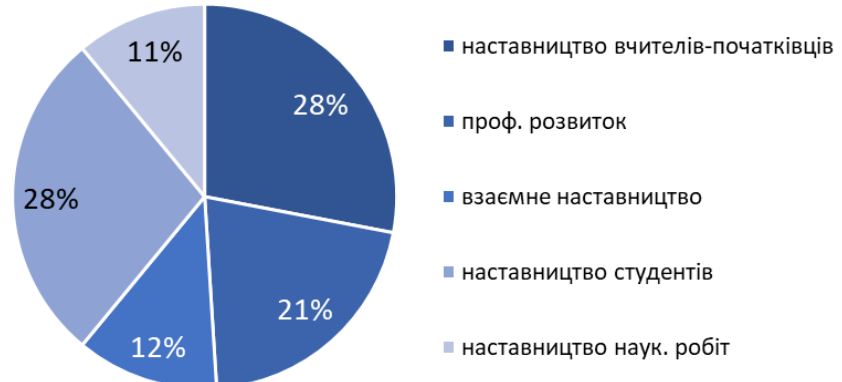

Рис. 1. Розподіл публікацій за категоріями у межах теми "Наставництво"

Практично половина (49\%) публікацій присвячено наставництву в контексті початкового й постійного професійного розвитку вчителів і викладачів іноземних мов. Іншу велику групу (39\%) складають публікації щодо аудиторного або позааудиторного наставництва студентів та учнів, включно з наставництвом під час написання наукових робіт, де підлеглі наставників (магістранти, аспіранти тощо) фактично є студентами. На рис. 2 відображено динаміку кількості публікацій за обраними категоріями.

3 огляду на порівняно невеликий обсяг аналізованої бази важко робити статистично значущі узагальнення. Проте помітна загальна тенденція щодо деякого збільшення цікавості до теми наставництва, починаючи з середини останнього десятиліття. Нижче подано переліки та загальний огляд публікацій згідно з окресленими категоріями.

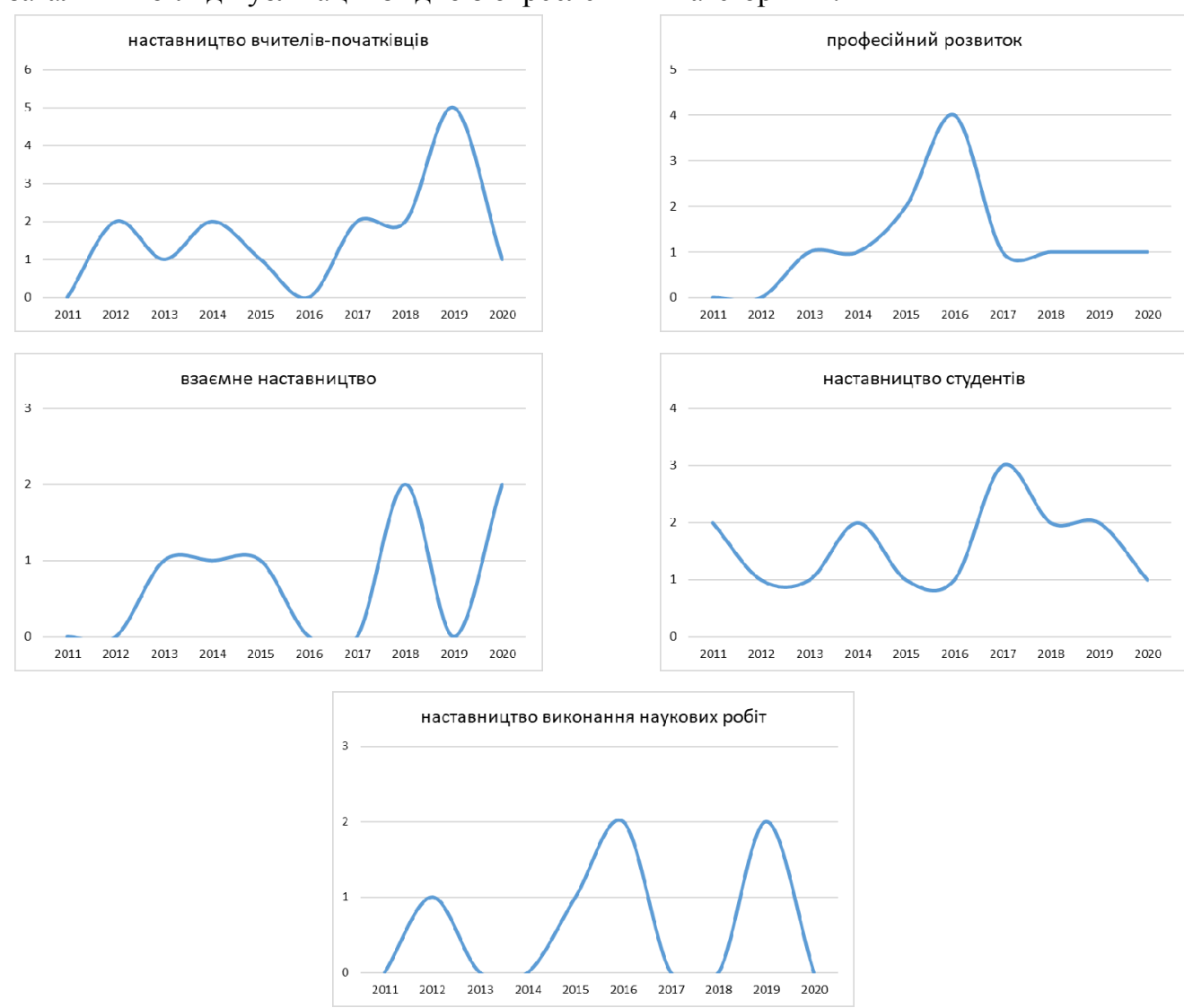

Рис. 2. Динаміка кількості публікацій за категоріями у межах теми "Наставництво” 
Наставництво студентів та учнів. Наставництво студентів та учнів в умовах аудиторної та позааудиторної роботи визначається дослідниками як один з вагомих і корисних інструментів освітнього процесу. Статті в межах цієї категорії $є$ досить різноманітними як з точки зору організації досліджень, так і з точки зору дослідницької проблематики. Так, низка досліджень сфокусована на проблемах стратегій наставництва. Досліджено, як стратегії ініціації та підтримки наставництва опосередковують вплив акультуративного стресу та міжкультурної комунікативної компетентності на рівень задоволення аспірантів освітньою програмою (Yang, Orrego Dunleavy \& Phillips, 2016). Здійснено огляд стратегій наставництва, як частини програм 3 вивчення англійської мови як іноземної в університетах і коледжах США (Thompson, 2013; Dobrowolska $\&$ Balslev, 2017). Зокрема 3'ясовано, як наставники скеровують навчання майбутніх учителів шляхом тріадичних бесід, що дозволяють встановити тісніший зв'язок між учасниками освітнього процесу і подолати розрив між теорією і практикою (Dobrowolska \& Balslev, 2017).

Проаналізовано потенціал наставництва у контексті навчання англійської як іноземної (Samimy, Kim, Ah Lee \& Kasai, 2011). 3 огляду на попереднє дослідження автори вказують на різні шляхи реалізації наставництва у навчальних колективах, зокрема спільне виконання дослідницьких проєктів викладачем-ментором і студентом-старшокурсником або спільний виступ на конференціях. Разом з тим підкреслено вагомість формального оформлення та визнання такої роботи на рівні структурного підрозділу ЗВО з метою ії зарахування у вигляді навчальних кредитів для студентів та частини навантаження / процедур постійного професійного розвитку для викладачів.

Досліджено окремі аспекти наставництва. Так, статтю (Laminack, 2017) зосереджено на аналізі поняття "mentor text" (навчальні тексти або тексти-зразки - тексти різних типів і жанрів, на основі яких можна здійснювати навчання певних аспектів писемного мовлення), порівнюючи особливості використання таких текстів 3 процесом наставництва у процесі формування компетентності в письмі. У фокусі дослідженні (Wang, 2012) перебували повідомлення, отримані студентами коледжу від їхніх наставників на кампусі про коледж і сім'ю. Інтерв'ю студентів коледжу першого покоління виявили 5 основних тем таких повідомлень: 1) прагнення до академічного успіху, 2) цінність школи, 3) нарощування майбутнього потенціалу, 4) прийняття рішень, 5) підтримка й заохочення. зосереджене на Досліджено вплив основних навчальних комунікативних здібностей учителів, наприклад, невербальної безпосередності (nonverbal immediacy) на процес сприйняття студентами інформації від наставника (Kerssen-Griep \& Witt, 2015). Продемонстровано ефективність програми двомовних наставників для розвитку (не)когнітивних або мовленнєвих умінь студентів перших і старших курсів університету Гранади (Іспанія) (Arco-Tirado, Fernández-Martín \& HernándezMoreno, 2018). В контексті теорії позиціонування як аналітичного інструменту з'ясовано, в який спосіб практики навчання грамотності впливають на позиціонування наставника, а також як саме наставники позиціонують себе та як їх позиціонує оточення (Frankel, Fields, Kimball-Veeder \& Murphy, 2018).

Блок аналітичних есе журналу Communication Education (том 68, номер 1, 2019) присвячено різним аспектам наставництва у вищій освіті. Акцентовано різні аспекти наставництва у вищій школі, зокрема комунікативні стратегії взаємодії наставників та їхніх підлеглих, моделі реалізації наставництва, усунення 3 процесу наставництва дискримінаційних практик, відмінності між способами здійснення наставництва з різними категоріями студентів (Harris \& Lee, 2019; Waldeck, 2019; Phillips \& Adams, 2019; Rudick \& Dannels, 2019).

Акцентовано особливості е-менторингу та використання електронних засобів у процесі наставництва студентів та учнів (Mc Call, 2011; del Rosal, Conry \& Wu, 2017; O'Dowd, Sauro $\&$ Spector Cohen, 2020). Одним із п'яти напрямів, необхідних для глибшого розуміння дистанційного навчання іноземних мов, $\epsilon$ дослідження практик наставництва та їхнього впливу на учасників цього процесу (White, 2014). Дотично до проблеми наставництва розглянуто 
дослідницьку проєктну роботу майбутніх учителів, які оволодівають курсом комп'ютерних технологій навчання іноземних мов у німецьких університетах (Cutrim Schmid \& Hegelheimer, 2014).

Arco-Tirado, J. L., Fernández-Martín, F. D., \& Hernández-Moreno, N. (2018). Skills learning through a bilingual mentors program in higher education. International Journal of Bilingual Education and Bilingualism, 21(8), 1030-1040. https://doi.org/10.1080/13670050.2016.1228601

Cutrim Schmid, E., \& Hegelheimer, V. (2014). Collaborative research projects in the technologyenhanced language classroom: Pre-service and in-service teachers exchange knowledge about technology. ReCALL, 26(3), 315-332. doi:10.1017/S0958344014000135

Del Rosal, K., Conry, J., \& Wu, S. (2017). Exploring the fluid online identities of language teachers and adolescent language learners. Computer Assisted Language Learning, 30(5), 390-408. https://doi.org/10.1080/09588221.2017.1307855

Dobrowolska, D., \& Balslev, K. (2017). Discursive mentoring strategies and interactional dynamics in teacher education. Linguistics and Education, 42, 10-20. https://doi.org/10.1016/j.linged.2017.09.001

Frankel, K. K., Fields, S. S., Kimball-Veeder, J., \& Murphy, C. R. (2018). Positioning adolescents in literacy teaching and learning. Journal of Literacy Research, 50(4), 446-477. https://doi.org/10.1177/ 1086296X18802441

Harris, T. M., \& Lee, C. N. (2019). Advocate-mentoring: a communicative response to diversity in higher education. Communication Education, 68(1), 103-113. https://doi.org/10.1080/ 03634523.2018.1536272

Kerssen-Griep, J., \& Witt, P. L. (2015). Instructional feedback III: How do instructor facework tactic sand immediacy cues interact to predict student perceptions of being mentored? Communication Education, 64(1), 1-24. https://doi.org/10.1080/03634523.2014.978797

Laminack, L. (2017). Mentors and mentor texts: What, why, andhow? Reading Teacher, 70(6), 753-755. doi:10.1002/trtr.1578

McCall, I. D. (2011). My Uni Space: Applying e-mentoring to languag elearning. Language Learning Journal, 39(3), 313-328. https://doi.org/10.1080/09571736.2010.538950

O'Dowd, R., Sauro, S., \& Spector Cohen, E. (2020). The role of pedagogical mentoring in virtual exchange. TESOL Quarterly, 54(1), 146-172. https://doi.org/10.1002/tesq.543

Phillips, A. L., \& Adams, T. E. (2019). Suitcase, crockpot, car: mentoring relationships, cultivating confidence, and challenging workplaces for the emerging professional. Communication Education, 68(1), 121-128. https://doi.org/10.1080/03634523.2018.1538524

Rudick, C. K., \& Dannels, D. P. (2019). "Yes, and ... *”: continuing the scholarly conversation about mentoring in higher education. Communication Education, 68(1), 128-131. https://doi.org/10.1080/ 03634523.2018 .1538523

Samimy, K., Kim, S., Ah Lee, J., \& Kasai, M. (2011). A participative inquiry in a TESOL program: Development of three NNES graduate students' legitimate peripheral participation to fuller participation. Modern Language Journal, 95(4), 558-574. https://doi.org/10.1111/ j.1540-4781.2011.01247.x

Thompson, A. S. (2013). Intensive English Programs in the United States: An Overview of Structure and Mentoring. TESOL Journal, 4(2), 211-232. https://doi.org/10.1002/tesj.55

Waldeck, J. H. (2019). Prosocial advocacy communication and mentoring in higher education. Communication Education, 68(1), 113-121. https://doi.org/10.1080/03634523.2018.1538525

Wang, T. R. (2012). Understanding the memorable messages first-generation college students receive from on-campus mentors. Communication Education, 61(4), 335-357. https://doi.org/10.1080/ 03634523.2012 .691978

White, C. (2014). The distance learning of foreign languages: A research agenda. Language Teaching, 47(4), 538-553. https://doi.org/DOI: 10.1017/S0261444814000196 
Yang, Q. (Candy), Orrego Dunleavy, V., \& Phillips, J. R. (2016). Are you satisfied? Exploring the mediating effects of mentoring communication strategies in predicting Chinese international graduate students' program satisfaction. Communication Education, 65(2), 182-203. https://doi.org/10.1080/03634523.2015.1090005

Наставництво вчителів-початківців. Робота 3 учителями, які починають професійну кар'єру, є одним 3 ключових напрямків наставництва в освіті. Ефективна професійна соціалізація вчителів-початківців потребує підтримки та допомоги більш досвідчених колег, особливо у випадках виникнення неочікуваних або напружених ситуацій. Наставники здатні надати важливу практичну інформацію, що може бути корисною для вчителів-початківців щодо подолання потенційних труднощів і досягнення успіху в професійній діяльності. Іншими словами, вчителі-початківці вчаться бути вчителями завдяки досвіду взаємовідносин 3 наставником.

Помітну кількість робіт на основі переважно якісних (qualitative) методів дослідження зосереджено на вивченні особливостей наставництва вчителів-початківців (Karimi \& Norouzi, 2017; Wang \& Bale, 2019). У першій статті дослідження сфокусовано на зміні педагогічних знань молодих учителів унаслідок роботи з професійними наставниками. Результати дослідження підтверджують прогнозовану думку щодо ефективності наставництва для розвитку професійної компетентності, у випадку його використання паралельно з практичною педагогічною діяльністю. У другій статті досліджено групу китайських учителів, які працюють в американських школах. Виявлено вплив різних професійних і культурних традицій учасників освітнього процесу, а також різних підходів до наставництва на ефективність його результатів. Подано огляд наукової літератури з проблем наставництва та навчання грамотності на початковому етапі підготовки вчителів (Hoffman et al, 2019). Обговорено проблеми й перспективи цього напрямку досліджень для трансформації підготовки вчителів шляхом впровадження нових практик наставництва. Колективом дослідників зі Словаччини (Billikova et al, 2014) проаналізовано практики наставництва у підготовці вчителів-початківців у цій країні та виявлено сильні й слабкі сторони наставництва як навчального інструменту. Проаналізовано проблеми співпраці наставників і вчителів-початківців щодо використання відеоспостережень для подальшої рефлексії й обговорення педагогічних практик і прикладів (Baecher \& McCormack, 2015).

Іншу досить чисельну групу досліджень присвячено аналізу й опису досвіду вчителівпочатківців, де з-поміж низки інших практик згадано й наставництво. Акцентовано роль менторів у формуванні у вчителів іноземних мов вміння професійної рефлексії на етапі їхнього професійного становлення (Playsted, 2019). 3'ясовуючи проблемні складові підготовки вчителівпочатківців (teacher candidates) до предметно-мовного інтегрованого викладання, вказано на необхідність наставництва на початковому етапі професійної діяльності як однієї з основних передумов якісного викладання (Tigert \& Peercy, 2018). Автори рекомендують університетам налагодити та підтримувати зв'язки з вчителями, які мають значний досвід і потенціал до виконання ролі наставників. 3'ясовано проблеми первинної професійної соціалізації вчителів іноземних мов (Hennebry-Leung, Gayton, Hu \& Chen, 2019). Автори підкреслюють надзвичайно важливу роль професійної спільноти у реалізації наставництва. Описано досвід участі вчителів у програмі професійного розвитку, реалізованій у партнерстві між університетом, громадською організацією та міським навчальним округом (del Rosal, Roman \& Basaraba, 2018). Крім іншого, зазначено, що в межах програми вчителі отримували менший обсяг наставництва порівняно з традиційними програмами, що дещо негативно вплинуло на ії кінцеві результати. Проаналізовано підготовку вчителів-початківців до навчання читання учнів початкової школи (Hendry, 2020, де одним з елементів такої підготовки є наставництво. За допомогою інтегрованих якісних і кількісних методів досліджено уявлення вчителів-початківців англійської мови щодо соціальної підтримки та професійної ефективності (Brannan \& Bleistein, 2012). Досліджено 
досвід підтримки вчителів-початківців у Гонконзі (Китай) (Mann \& Tang, 2012). Автори описують досвід первинної професійної соціалізації, особливо акцентуючи індукцію та наставницьку підтримку, яку вчителі отримують протягом першого року роботи.

Деякі статті розглядають проблеми наставництва у ширшому, програмному контексті. Порівняно програми Secondary English Post Graduate Certificate of Education для початкової педагогічної освіти в Брістольському університеті (Великобританія) з програмою в університеті Мальти (Smith \& Spiteri, 2013). Основну увагу автори приділяють змісту відповідних програм і ролі шкільного наставника у таких програмах. Дж. Ходжсон (Hodgson, 2014) аналізує зміни в системі початкової підготовки вчителів Великобританії, одним з елементів якої є наставництво. Висловлено сумніви в доцільності урядових новацій та очікуваному зменшенні обсягу наставницької допомоги.

Окремий блок публікацій складають дослідження, зосереджені на технічних засобах i середовищах навчання, безпосередньо пов'язаного 3 наставництвом. Проаналізовано наставництво у віртуальному середовищі та за допомогою технічних засобів з описом процедур та особливостей їх використання (Sato \& Chen, 2019), а також переваги й недоліки участі у менторській програмі ; Guiamos!, що була реалізована в змішаному форматі (аудиторно й онлайн) (Riley, Muñoz, Green, \& Kim, 2017).

Baecher, L., \& McCormack, B. (2015). The impact of video review on supervisory conferencing. Language and Education, 29(2), 153-173. https://doi.org/10.1080/09500782.2014.992905

Billikova, A., Gadusova, Z., Hartanska, J., Hockickova, B., Kissova, M., Lomnick, I., ...Zilova, R. (2014). Key competencies of mentor teachers essential for successful mentoring of novice teachers: A research study. XLinguae, 7(4), 55-74.

Brannan, D., \& Bleistein, T. (2012). Novice ESOL teachers' perceptions of social support networks. TESOL Quarterly, 46(3), 519-541. https://doi.org/10.1002/tesq.40

Del Rosal, K., Roman, D., \& Basaraba, D. (2018). Debemos escuchar a los maestros: Perspectives of bilingual teacher candidates in teacher education partnerships. Bilingual Research Journal, 41(2), 187-205. https://doi.org/10.1080/15235882.2018.1456986

Hendry, H. (2020). Becoming a teacher of early reading: charting the knowledge and practices of pre-service and newly qualified teachers. Literacy, 54(1), 58- 69. https://doi.org/10.1111/lit.12184

Hennebry-Leung, M., Gayton, A., Hu, X. A., \& Chen, X. (2019). Transitioning from master's studies to the classroom: From theory to practice. TESOL Quarterly, 53(3), 685-711. https://doi.org/10.1002/tesq.505

Hodgson, J. (2014). Surveying the wreckage: The professional response to changes to initial teacher training in the UK. English in Education, 48(1), 7-25. https://doi.org/10.1111/eie. 12028

Hoffman, J. V., Svrcek, N., Lammert, C., Daly-Lesch, A., Steinitz, E., Greeter, E., \& DeJulio, S. (2019). A research review of literacy tutoring and mentoring in initial teacher preparation: Toward practices that can transform teaching. Journal of Literacy Research, 51(2), 233-251. https://doi.org/10.1177/1086296X19833292

Karimi, M. N., \& Norouzi, M. (2017). Scaffolding teacher cognition: Changes in novice L2 teachers' pedagogical knowledge base through expert mentoring initiatives. System, 65, 38-48. https://doi.org/10.1016/j.system.2016.12.015

Mann, S., \& Tang, E. H. H. (2012). The role of mentoring in supporting novice English language teachers in Hong Kong. TESOL Quarterly, 46(3), 472-495. https://doi.org/10.1002/tesq.38

Playsted, S. A. (2019). Reflective practice to guide teacher learning: A practitioner's journey with beginner adult English language learners. Iranian Journal of Language Teaching Research, 7(3), 37-52. Retrieved from http://ijltr.urmia.ac.ir/article_120735.html

Riley, J., Muñoz, A., Green, L. C., \& Kim, J. H. (2017). ¡Guiamos!: A university-based program for pre-service bilingual and ESL teachers. Bilingual Research Journal, 40(4), 406-423. https://doi.org/10.1080/15235882.2017.1385547 
Плотніков $С$. О., Гошилик В. Б. Наставництво в галузі навчання іноземних мов: анотована бібліографія

Sato, E., \& Chen, J. C. (2019). Rise to the occasion: The trajectory of a novice Japanese teacher's first online teaching through action research. Language Teaching Research. https://doi.org/10.1177/ 1362168819846794

Smith, L., \& Spiteri, D. (2013). A Tale of Two Cities: A comparison of the PGCE Secondary English programmes at the Universities of Bristol and Malta, with particular emphasis on the student teachers' school-based experience and the role of the mentor. English in Education, 47(3), 213-228. https://doi.org/10.1111/eie.12027

Tigert, J. M., \& Peercy, M. M. (2018). Preparing to teach both content and language: Four ESOL teacher candidates' experiences. TESOL Journal, 9(3), 542-556. https://doi.org/10.1002/tesj.358

Wang, W., \& Bale, J. (2019). Mentoring for new secondary Chinese language teachers in the United States. System, 84, 53-63. https://doi.org/10.1016/j.system.2019.05.002

Наставництво вчителів. Такий різновид наставництва $\epsilon$ елементом неперервного професійного розвитку. Мета наставництва вчителів-практиків полягає в тому, щоб надати їм необхідну підтримку, супровід, а також поради, що дозволять удосконалити професійну компетентність. Наставництво зазвичай реалізується у контексті формальних і неформальних програм професійного розвитку вчителів, наприклад: програми підтримки реалізації досліджень шкільними вчителями, запропонованої університетом ім. Султана Кабуса (Султанат Оман) (Al-Maamari, Al-Aamri, Khammash \& Al-Wahaibi, 2017); програми сприяння науковому дослідницькому письму вчителів іноземних мов, реалізованої в університетах Туреччини (Dikilitaş \& Mumford, 2016); програми співпраці університетських менторів і вчителів початкової школи Сінгапуру для розробки й запровадження нових стратегій навчання читання (Silver \& Png, 2016).

Місце наставництва під час розвитку вмінь рефлексії у досвідчених вчителів описано в статті (Munalim \& Gonong, 2019). Рефлексія вчителів під час заходів постійного професійного розвитку є також об'єктом дослідження (Mann, Crichton \& Edmett, 2020), в якому група тайських вчителів за допомогою наставників розвивала професійну компетентність шляхом рефлективного аналізу відеозаписів власних уроків і занять колег. Шляхом конверсаційного аналізу розглянуто, як певні прийоми наставництва стимулюють рефлексію вчителів (Zhang, 2014). Проаналізовано вплив прийомів і практик на рефлексію вчителів (Waring, 2013). Результати дослідження проливають світло на особливості того, що відбувається на рівні взаємодії під час зустрічей наставника і вчителя в контексті професійного розвитку вчителів іноземної мови. Використовуючи програму підготовки менторів як основу для дослідження, акцентовано прийоми надання порад і задавання запитань, що стимулюватимуть рефлексію вчителів під час роботи з ментором (Smith \& Lewis, 2015).

3 опертям на практики дослідницького проекту в Пуерто-Рико проаналізовано досвід міждисциплінарного наставництва у вищій освіті й акцентовано необхідність розвитку наставницьких мереж, що сприятимуть професійному розвитку викладачів та підвищенню якості наукових досліджень (Martínez-Roldán \& Quiñones, 2016). На основі емпіричних даних, отриманих під час використання онлайн-програми e-Tutory в турецьких університетах, вказано вагомість наставництва в процесі підготовки викладачів іноземних мов до викладання у онлайн середовищі (Adnan, 2018). Описано вагомість професійних спільнот і можливості використання технічних засобів (Voice Thread, Todays Meet, Poll Everywhere, Blend space) для наставництва (Bates, Huber \& McClure, 2016).

Досліджено набуття професійних педагогічних знань вчителями завдяки використанню підходу до навчання прагматики іноземної мови, відомого як “концептуальне навчання прагматики” (concept-based pragmatics instruction), на основі теорій Л. С. Виготського (van Compernolle \& Henery, 2015). Одним з елементів підходу є організація наставницьких зустрічей з експертом. 
Adnan, M. (2018). Professional development in the transition to online teaching: The voice of entrant online instructors. ReCALL, 30(1), 88-111. doi:10.1017/S0958344017000106

Al-Maamari, F., Al-Aamri, K., Khammash, S., \& Al-Wahaibi, M. (2017). Promoting EFL teacher research engagement through a research support programme. RELC Journal, 48(3), 389-404. https://doi.org/10.1177/0033688216684282

Bates, C. C., Huber, R., \& McClure, E. (2016). Stay connected: Using technology to enhance professional learning communities. Reading Teacher, 70(1), 99-102. https://doi.org/10.1002/trtr.1469

Dikilitaş, K., \& Mumford, S. E. (2016). Supporting the writing up of teacher research: peer and mentor roles. ELT Journal, 70(4), 371-381. doi: 10.1093/elt/ccw014

Mann, S., Crichton, R., \& Edmett, A. (2020). Evaluating the role of video in supporting reflection beyond INSET. System, 90, 102195. https://doi.org/10.1016/j.system.2019.102195

Martínez-Roldán, C. M., \& Quiñones, S. (2016). Resisting erasure and developing networks of solidarity: Testimonios of two Puerto Rican scholars in the academy. Journal of Language, Identity and Education, 15(3), 151-164. https://doi.org/10.1080/15348458.2016.1166059

Munalim, L. O., \& Gonong, G. O. (2019). Stances in student -teachers' spoken reflection: An exploratory linguistic study to enhance a reflection inventory. Iranian Journal of Language Teaching Research, 7(1), 119-139. Retrieved from http://ijltr.urmia.ac.ir/article_120636.html

Silver, R. E., \& Png, J. (2016). Learning to Lead Reading Comprehension Discussion. RELC Journal, 47(1), 71-78. https://doi.org/10.1177/0033688215609217

Smith, M. K., \& Lewis, M. (2015). Toward facilitative mentoring and catalytic interventions. ELT Journal, 69(2), 140-150. doi: 10.1093/elt/ccu075

Van Compernolle, R. A., \& Henery, A. (2015). Learning to do concept-based pragmatics instruction: Teacher development and L2 pedagogical content knowledge. Language Teaching Research, 19(3), 351-372. https://doi.org/10.1177/1362168814541719

Waring, H. Z. (2013). Two mentor practices that generate teacher reflection without explicit solicitations: Some preliminary considerations. RELC Journal, 44(1), 103-119. https://doi.org/10.1177/ 0033688212473296

Zhang, H. W. (2014). Mentor invitations for reflection in post-observation conferences: Some preliminary considerations. Applied Linguistics Review, 5(1), 99-123. https://doi.org/10.1515/ applirev-2014-0005

Взаємне наставництво. Ще одним варіантом наставництва $\epsilon$ взаємне наставництво (peer-mentoring). Такий різновид наставництва має місце, коли у групі двох або більше людей, які мають певні спільні професійні характеристики (наприклад, вік, посада тощо), кожен учасник передає іншим певний досвід та/або знання. При цьому процес обміну є обопільним, навіть якщо хтось $з$ учасників групи має більший досвід та/або знання у певній галузі. Взаємне наставництво має свої переваги та недоліки, проте цілком очевидно, що відсутність ієрархічних стосунків сприятиме відкритішому спілкуванню між учасниками. Зазначимо, що в науковій літературі поняття взаємного наставництва часом вживається синонімічно 3 поняттям взаємного коучингу (peer-coaching), що в багатьох випадках зумовлено значною схожістю цих процедур.

Аналізовані статті цієї категорії є досить різноманітними та спрямованими на розв'язання різних дослідницьких завдань. Досліджено розвиток грамотності іспаномовних студентів, які брали участь у обов'язкових позааудиторних сесіях взаємного наставництва (ReznicekParrado, Patiño-Vega \& Colombi, 2018). Унаслідок програми досягнено розвиток компетентності у використанні академічної мови та проаналізовано роль викладача-однолітка як фасилітатора цього процесу. Досліджено, як взаємне наставництво в середовищі майбутніх учителів іноземних мов сприяс розвитку професійної рефлексії (Nguyen \& Ngo, 2018). Для організаторів педагогічної освіти надано не лише корисну інформацію, але й також пропагується використання взаємного 
наставництва для розвитку вмінь професійної взаємодії студентів. Роботи (Cremin et al, 2020) та (Hansen-Thomas \& Richins, 2015) присвячено пошуку особливостей взаємодії та спільного впливу двох груп менторів, що складалися 3 досвідчених освітян. У першому випадку досліджено вплив на результати студентів спільної роботи вчителів та викладачів письма у межах програми "Вчителі як письменники" (Teachers as Writers), а у другому - розвиток професійних компетентностей внаслідок спільного наставництва під час роботи групи вчителів іноземної мови як наставників з учителями-предметниками з сільських шкіл.

Досліджено можливості взаємного навчання та наставництва студентів під час використання онлайн-платформ (вікі та Symbaloo $E D U$ ) і попри загальну позитивну оцінку підкреслено необхідність чіткого планування та мониторингу процедур взаємного навчання (Wang, Zou, Wang, \& Xing, 2013; Harwood, 2014). Розкрито особливості колаборативного письма студентів з використанням текстового редактора MS Word та з'ясовано місце в цьому процесі взаємного наставництва (Hafner, С. А., \& Yu, 2020).

Cremin, T., Myhill, D., Eyres, I., Nash, T., Wilson, A., \&Oliver, L. (2020). Teachers as writers: learning together with others. Literacy, 54(2), 49-59. https://doi.org/10.1111/lit.12201

Hafner, C. A., \&Yu, C. (2020). Language Socialization in Digitally Mediated Collaborative Writing: Evidence from Disciplinary Peer and Teacher Feedback. RELC Journal, 51(1), 14-32. https://doi.org/10.1177/0033688220901347

Hansen-Thomas, H., \& Richins, L. G. (2015). ESL mentoring for secondary rural educators: Math and science teachers become second language specialists through collaboration. TESOL Journal, 6(4), 766-776. https://doi.org/10.1002/tesj.221

Harwood, C. (2014). Personal learning environments: Using Symbaloo EDU in learning English for academic purposes. ESP Today, 2(2), 199-215.

Nguyen, H. T. M., \& Ngo, N. T. H. (2018). Learning to reflect through peer mentoring in a TESOL practicum. ELT Journal, 72(2), 187-198. doi: 10.1093/elt/ccx053

Reznicek-Parrado, L. M., Patico-Vega, M., \& Colombi, M. C. (2018). Academic peer tutors and academic biliteracy development in students of Spanish as a heritage language. Journal of Spanish Language Teaching, 5(2), 152-167. https://doi.org/10.1080/23247797.2018.1538358

Wang, J., Zou, B., Wang, D., \& Xing, M. (2013). Students' perception of a wiki platform and the impact of wiki engagement on intercultural communication. System, 41(2), 245-256. https://doi.org/https://doi.org/10.1016/j.system.2013.04.004

Наставництво виконавців наукових робіт. Одним з традиційних напрямків наставництва $€$ допомога у написанні студентами й аспірантами дослідницьких наукових робіт. Незважаючи на, здавалось би, прямолінійність й однозначність цього процесу, розгляд його під різними кутами зору дозволяє виявити часом досить несподівані його особливості. Наприклад, теорія ментальної реалізації наставництва (mentoring enactment theory) прагне пояснити, що саме спонукає людей вступати в наставницькі відносини, як вони висловлюють зацікавленість в їх ініціюванні й чому наставницькі відносини підтримуються та повторюються. В межах теорії припускається, що ключову роль в ініціації, підтримці й повторенні відносин наставництва відіграє комунікація. Продемонстровано, що наставники та їхні підлеглі мають загалом спільне бачення того, якими мають бути дії обох сторін наставництва (Mansson \& Myers, 2012). 3-поміж таких дій виявлено підтримку, захист, чемність, формулювання цілей і надання завдань. Запропоновано інструмент оцінки функцій наукового керівника (Carpenter, Makhadmeh, \& Thornton, 2015). Результати емпіричної перевірки продемонстрували, що з основними функціями наукового керівника (кар'єрними, психологічними, дослідницькими, інтелектуальними) суттєво пов’язані його дослідницька активність, вибір методів дослідження, академічний ранг і самоефективність.

Досліджено проблеми взаємовідносин наставника та студента, який виконує наукове дослідження, з точки зору аналізу цитувань в академічному письмі (Omizo \& Hart-Davidson, 
2016). Автори пропонують комп'ютерні методи аналізу тексту, які можуть підвищити ефективність взаємодії наукового керівника та студента. Здійснено внесок у дискусію про підготовку наукових дисертацій (Bommarito, 2016), зокрема досліджено підхід до наставництва виконавців наукових робіт, який передбачає певну керовану діяльність на етапі, що передує написанню роботи. Розглянутий проєкт наставництва мав подвійну мету: здійснити якісне наукове дослідження та сприяти професійному розвитку учасників.

Також досліджено місце та роль фактору гендеру в процесі наставництва аспірантів (Sánchez-Martín \& Seloni, 2019). Автори обгрунтовують можливості “феміністичного наставництва", а також вказують на важливість рефлексивних методів під час взаємодії наставника й учня. Зазначимо, що в наведеному вище дослідженні (Mansson \& Myers, 2012) не виявлено статистично значущих ознак впливу гендеру на процес наставництва під час керування науковими роботами.

Bommarito, D. V. (2016). Collaborative research writing as mentoring in a U.S. English doctoral program. Journal of Writing Research, 8(2), 267-299. https://doi.org/10.17239/jowr-2016.08.02.04

Carpenter, S., Makhadmeh, N., \& Thornton, L. J. (2015). Mentorship on the Doctoral Level: An Examination of Communication Faculty Mentors' Traits and Functions. Communication Education, 64(3), 366-384. https://doi.org/10.1080/03634523.2015.1041997

Mansson, D. H., \& Myers, S. A. (2012). Using mentoring enactment theory to explore the doctoral student-advisor mentoring relationship. Communication Education, 61(4), 309-334. https://doi.org/10.1080/03634523.2012.708424

Omizo, R., \& Hart-Davidson, W. (2016). Finding genre signals in academic writing. Journal of Writing Research, 7(3), 485-509. https://doi.org/10.17239/jowr-2016.07.03.08

Sánchez-Martín, C., \& Seloni, L. (2019). Transdisciplinary becoming as a gendered activity: A reflexive study of dissertation mentoring. Journal of Second Language Writing, 43, 24-35. https://doi.org/10.1016/j.jslw.2018.06.006 